\title{
Long Distance Solidarity: Polish Public Opinion and the Boer War 1899-1902
}

\author{
PIOTR SZLANTA \\ University of Warsaw \\ Instytut Historyczny \\ Wydział Historyczny \\ Uniwersytet Warszawski \\ ul. Krakowskie Przedmieście 26/28 \\ 00-927 Warszawa, Poland \\ p.szlanta@uw.edu.pl
}

\begin{abstract}
The bloody conflict which was taking place in South Africa in the years 1899-1902 was followed with a great interest by Polish public opinion. Its greatest part strongly sympathized with the Boer republics. Their burgers were idealized and presented by the Polish press as brave fighters for independence, who dared to stand up against the world empire to defend their rights while Great Britain was attributed full responsibility for the outbreak of the war. For many Poles the Boers personified the general idea of freedom fighters and symbolized all suppressed nations. Their sad fate seemed to be quite similar to the Polish one and this similarity was the main source of sympathy toward defenders of the Transvaal and Free Orange State. Voices of few Polish intellectuals, who called for a more objective and not so emotional view on the war, could not change the pro-Boers stance of the greatest part of Polish public opinion.
\end{abstract}

Keywords: Second Boer War; Poland; public opinion; struggle for independence

The second Boer War or the Great War for Independence (1899-1902) attracted the attention of European public opinion, which followed, in detail, the bloody struggles in South Africa (Kröll 1973; Noer 1978; Rosenbach 1981; Pottinger 1986; 
Davidson and Filatova 1998; Teulié 2000; McCracken 2003; Bender 2009; Kuoitenbrouwer 2012). Poles - who from the end of $18^{\text {th }}$ century had been deprived of their own statehood and whose country had been divided between Russia, Prussia and Austria - were not exceptional here.

The Polish were not directly involved in colonial conflicts. They were repeatedly trying to regain their own independence following the motto "For our and your freedom" and taking part in many European internal conflicts and wars in the long $19^{\text {th }}$ century. Relentlessly suppressed by Russian troops, their last attempt to regain freedom was in 1863/1864 - the so called "January Uprising." Since the Russians introduced their denationalization policy against the Polish population, Poles were especially sensitive to all freedom movements. The aim of this article is to analyze the public debate on the Second Boer War, which took place in Poland at the time when it was partitioned between its neighbors. Even a cursory look at the Polish press from the time of the war reveals a huge number of articles on this, from the Polish perspective, distant and exotic war. In this contribution I will try to answer the following questions: what did Poles think about the war? Whom did they blame for the outbreak of the conflict? With which side did they sympathize? How did they see the solving of the British-Boer conflict? Was there any specific Polish perspective of the war in South Africa? The main sources for this article consist of the Polish press from the period of the Anglo-Boer War, published in all three parts of partitioned Poland and selected memoirs of Polish politicians and publicists.

As in all of Europe, the Polish press followed the events in South Africa with great interest and provided detailed coverage. During the last months of 1899 and first several months of 1900, these events seldom left the first pages of newspapers. Not until the occupation of the Orange Free State, the seizure of the Transvaal's main industrial and urban centers and the outbreak of the Boxer Uprising in China, did the topic of the war recede into the background. Later, it reoccurred as feature articles on the occasion of Paulus Kruger's visit to Europe, when reporting high mortality rate in concentration camps, Boer raids into the Cape Colony and the peace of Vereeniging.

Already at the beginning of hostilities the Polish nation carefully followed the British-Transvaal conflict, which resulted in a war. Perhaps the most distinctive proof of the keen interest that Poles had in the war could be found in the contemporary press. Without any doubt, the greatest part of Polish public opinion blamed British politicians, especially Prime Minister Lord Salisbury, Secretary of Colonies Joseph Chamberlain and the "bad spirit" of the British-Boer relations Cecil Rhodes for the outbreak of the war (KP ${ }^{1}$ 5.11.1899, KP 30.12.1899;

${ }^{1}$ List of abbreviations: Cz - Czas, GG - Gazeta Grudziadzka, GW - Gazeta Warszawska, Ko - Kolce, Kr Kraj, KL - Kurjer Lwowski, KP - Kuryer Poznański, KŚ - Kuryer Świateczny, KW - Kurier Warszawski, 
KW, 12.12.1899; GW 20.12.1899; Nałkowski 1904: 76-77). Poles distrusted the main motive given by the British to legitimize hostilities, namely that the intervention was supposed to improve the legal status of foreigners in the Transvaal, so-called uitlanders, by giving them political rights. Polish commentators claimed that the British aggression stemmed from their desire to take over the complete control of the rich goldfields in the Transvaal and to remove the last obstacle before establishing a united South Africa under the British rule. The British politicians and entrepreneurs were accused of manipulating the already aged Queen Victoria and through intrigues acquiring her consent to launch the war (Sł 13.03.1900; GW 2.10.1899). According to the liberal Nowa Reforma from Austrian-Poland, the war was triggered also by the chauvinistic British public opinion (NR 13.10.1899). Stanisław Koszucki from Tygodnik Ilustrowany did not hesitate to label the Britons as "nation-animal" which was showing a highwayman instinct (TI 21(19).10.1899). On the other hand, not surprisingly, anti-Semites blamed in Nowa Niwa the Jews for triggering the war, who allegedly seized the control over the British government and parliament with the intention of capturing the Transvaal's gold fields (NN 10.03.1900).

Assuming a distanced stance, the liberal Przeglad Tygodniowy wrote several weeks after the beginning of the war: "If he [a sensible person, P.Sz.] reaches for a local newspaper and reads about the raging war, one must have sad feelings of pity and repugnance. Some kind of madness, some kind of doggedness emanates from those poor articles [...] to the Afrikaners' 'advantage'" (PT 18.11.1899). In December 1899 and January 1899, the doyen of Polish socialistic movement Bolesław Limanowski wrote in Przedświt, a monthly published on emigration in London: "Maybe imagination is bringing to some of us another, closer to our heart, picture of a battlefield, other, closer to our heart, ranks of fatherland's defenders, standing for a final battle against an overpowering invader. And these Vistula river's marsh meadows, filled with the blood of many generations [...] tell us to look at the fight for the Transvaal's rights with more compassion [...]."

The Polish public opinion did not absolve the British. Most of the British accepted the war on account of the benefits it could bring, despite knowing how unjust it was. The British were accused of hypocrisy, selfishness, corruption and treachery. The Transvaal's dependency on the British Crown was totally denied and it was recognized as an entirely independent and sovereign state. The Polish press did not even try to analyze the very complicated and somewhat undefined constitutional connection between these states. Gazeta Warszawska wrote: "What are these rights? If the right to some land is achieved by violence against the will of the natives, then not the British but the Dutch, who first begun to settle there,

NN - Nasza Niwa, NR - Nowa Reforma, Mu - Mucha, PT - Przeglad Tygodniowy, Sł - Słowo, TI - Tygodnik Ilustrowany, ZE - Zwiastun Ewangeliczny. 
expelled the Negroes. The English only came later" (GW 20.08.1899). London assured that their intervention in South Africa was only to defend the natives. This was not taken seriously, bearing in mind that the British themselves conquered the Zulus and the Matabele a few years before. British defeats during the first stage of the war pleased most Poles (Ko 6.(18).11.1899). Nowa Reforma stated in January 1900 that if half a year earlier somebody had expected defeats of the British troops, they would have been laughed at (NR 12.01.1900). In an article titled "Angielski Sedan" [English Sedan - a clear reference to the decisive French defeat in the war with Germany in 1870] published in Kurjer Lwowski one commentator prematurely judged that due to the last failures on the South African battlefields, the British military glory was lost forever (KL 20.12.1899). Kuryer Poznański commented caustically that British victories have such a surprising feature that in the course of time they are diminishing and that the British telegraphs reporting the situation on the front are not advantageous for the Queen Victoria's troops (KP 11.11.1899, KP 14.11.1899). One could find numerous cartoons and satiric poems poking fun at British military failures (Ko 25.09(7.10).1899, Ko 2.(14).10.1899; KŚ 20.01(2.02).1901).

After the Jameson's raid in 1896, this war gave the Polish readers a second occasion to be introduced to the problems of South Africa (Szlanta 1997: 45-64). A series of articles devoted to ethnic relations, history, geography, economy, climate, the genesis of the British-Boer conflicts and famous South Africans appeared in the Polish press. The fighting armies, their commanders and maneuvers, the course of their battles and information for diplomatic parlors were depicted in full detail. The greater part of the public opinion in Russian Poland presented an idealized picture of the Boer. The Boers' positive features were often expressed in a grotesque manner; as can be read in Gazeta Warszawska:

A Boer is a gallant and persistent warrior. From a young age he knows how to handle a weapon and doesn't fear any danger. He spends his whole life hunting or cultivating his farm and raising his cattle. He enjoys wide, open spaces and gets ill in the city. He despised the gold-digger who arrived in his country, only to make a fortune. A Boer is an African, an Afrikaner as he prefers to call himself. He loves his country, which he conquered with his own blood and will defend with his own blood. He is modest and brave, preserving his Dutch character: calmness and patience. He is never in a hurry and the gold-fever has no influence upon him. Towards foreigners he is distrustful but hospitable. A Boer speaks Dutch and is Dutch. He retained the purity of blood after a 250-year stay in Africa. There are Mulattoes in the whole of the Transvaal. A Boer is a model husband and respects only those who are married and have children. But he has one great weakness: he will never become reconciled to the modern civilization. (GW 6.01.1900) 
Other qualities, such as their diligence, peaceful attitude towards life and deep piety were also underlined. The Polish press defended the Boers against the British accusations of their inhumane policy towards the natives, lack of education and persecution of the Catholics.

Boer women were described as being loyal and devoted to their husbands. They were modest, thrifty, reserved in showing their emotions but energetic. They were admired for sending without hesitation their 13/14-year-old sons to the front. The burden of running the farm fell upon them and whenever necessary they took up arms themselves. The traditionalists gladly accepted the model Boer family with its many children. President Paul Kruger's wife, who was the embodiment of all of the above-mentioned features, symbolized the attitude of all Boer women in the Polish press (KW 22.12.1899; Sł 16.03.1900; KL 15.10.1899; Cz 8.10.1899).

The Polish press tried to find real but sometimes also imaginary Polish episodes in the war. Gazeta Grudziadzka, followed by a few other Polish newspapers, published articles on Poles living in the Transvaal, probably to draw even more interest to the South African conflict among their readers (GG 19.10.1899; GW 1.11.1899; KP 20.10.1899). Yet, the stories soon turned out untrue (KW 19.11.1899). Some titles informed also about a Polish volunteer troop allegedly fighting on the Boer side (Żukowski 1994: 89; KW 19.12.1899; Kr 22.12.1900 (4.01.1901)) and about Katarzyna Radziwiłłowa, a friend of Cecil Rhodes, who after his death, was taken to court for forging Rhodes's signatures on checks (Zins 2000: 308-309; GW 2.03.1902, GW 3.03.1902).

The situation of the natives, widely referred to as "Kaffirs," was largely omitted by the press. They were described as cruel savages, uncivilized and uneducated. They were criticized for their mass abstaining from work, drunkenness and plundering of stocks. Although cruel and harsh, the native policy of the Transvaal government was definitely the most effective [in dealing with the Bantus - P.Sz.] (GW 9.10.1899).

Only a few remarks regarding the factual attitudes of the Boers toward the Bantus and the Coloreds were made in the Polish press. The Lutheran Zwiastun Ewangeliczny probably most firmly stood up for the Bantu population. In November 1899 it wrote:

Let us not forget that the Africaanders are newcomers, invaders in their own country, a country which primary belonged to the black tribes who were treated like wild animals by those newcomers. The natives have no rights in their own country. They are not allowed to possess any ground, they do not have any schools, they are not permitted to go to Boer churches, they are even forbidden to walk in the streets of Pretoria. Black people pay various taxes and face all kinds of torture, imprisonment and flogging. 
The Boers seem to have forgotten one of the most important Christian obligations - love towards the poor. The Boers have lived in South Africa for more than 200 years and up to now have done nothing good for the natives. (ZE 3.(15.)11.1899)

The British, although they were the ones who provoked this unjust and atrocious war, were praised for expanding the civilization, abolishing slavery, educating the natives, taking care of their colonies and, contrary to the Boers, assisting in the activities of the mission. Zwiastun Ewangeliczny deplored the fact that two protestant nations were at war. Although it put the blame for the outbreak of the war on the British, it still commented: "Regardless of all the reasons, we don't dare to side with the Boers and condemn the British. It's difficult to pity the cruel oppressors, even though they are being wronged at present." It is important to note that these opinions were made by a monthly paper which was limited in circulation. The greatest part of the Polish population belonged to the Roman Catholic church and not even Evangelists read this paper. After the outbreak of the war Zwiastun Ewangeliczny stated: "If we had expressed our sympathy for the British and defended them at the beginning of this war, we certainly would have had quite a number of dissatisfied readers, taking into account that the public opinion in the Kingdom of Poland is largely on the side of the Boers" (ZE 2.(15.)07.1899). The dominant Roman-Catholic Church did not express their definite viewpoint on the war. However, those involved in the mission in Africa pointed to the liberal policy of the British colonial administration towards the activities of missionaries. At the same time, they were against the restrictive policy of the Transvaal Calvinist authorities.

Not only in the press, but also in books can we find more proof of the Polish interest in the Anglo-Boer War. Soon after the war, Paul Kruger's and Christian de Wet's memoirs were translated and published in Polish (De Wet 1903; Krüger 1903). Also, for example, recollections written by the foreign volunteer in South Africa Eugeniusz Augustus were published as Nad Tugela [By the Tugela River]. An author calling himself Janek Żórowski wrote Żotnierz De Weta [De Wet's soldier]. This book most probably was not a real account but a made-up story written on request since there was demand for such literature among Poles. French and German books regarding the Boers' struggle for independence were also translated into Polish. Bohater spod Spionkop [The hero from Spionkop], $W$ kraju mężnych Burów [In the land of the brave Boers] or Pieter Maritus are only a few examples. There were also books about the political and social situation in South Africa, like A. Seidler's Anglia i Burowie [England and the Boers]. Even Boers' military songs and the Transvaal's national anthem were translated and their music score and lyrics were published in the most popular daily newspapers and weekly magazines. The anthem was even publicly performed in Warsaw. 
Inhabitants of Warsaw also had the opportunity to admire a series of war photographs presented in Panopticum (GW 16.02.1899).

Taking into account what kind of influence the Boer issue had on the Polish society, a new form of entertainment was adopted. Jan Gebethner wrote in his memoirs that the director of the most popular circus in Warsaw, A. Cinissali, introduced a pantomime into the program. It was a scene showing an English armored train being blown up by the Boers. Everyone present, from those in the elegant boxes on the highest gallery to those having no seats, received the depiction of the British defeats with enthusiasm (Gebethner 1977: 79). This small episode illustrates well the general attitude in Warsaw: all social classes wished victory to the Boers. On one occasion, during a theatrical performance the Boers' national anthem was sung. Even children dressed up as Boer army generals at a fancy dress ball during the carnival season in early 1900. Pictures of the Boer leaders such as Kruger, Stein, Joubert and later Botha and the Wet were displayed in shop windows (GW 28.03.1900). These pictures were in a great demand at that time. Boer supporters in Warsaw often gathered in front of such windows where these pictures were shown and loudly expressed their opinions about the war. This support for the Boers was widespread, even though some manifestations of it could be perceived as humoristic, like for instance a Jew, selling watches in Warsaw, who declared himself a general watch tradesman for the Transvaal army, hoping it would increase his sales. One of the Warsaw hotels on Zielna street was renamed "Pretoria" (Kasprzycki 1997: il. 39).

Poles tried to transform their sympathy for the Boers into practical activity by collecting funds for the wounded and for the widows and orphans of those killed in action. The Augsburg-Evangelist Church was the first to start a charity campaign. It was initiated by Warsaw's superintendent G. Manitus. The money collected by the pastors was to be given directly to Dr. Willem Leyds, a representative of the Transvaal government in Europe (GW 17.11.1899). Fundraising was also arranged by some newspapers like Łódzki Rozwój. A part of the funds collected in the Kingdom of Poland was included in the Russian funds (GW 8.01.1900) and so the Russians offered Gen. Piet Cronje the "Bratina Cup" a cup made of bronze and silver, engraved with the names of cities involved in the charity, among which were Warsaw, Łódź and Kielce (Żukowski 1994: 91-92). Most likely, Poles also contributed to charities organized by the Russian press, by such papers as Novoje Vriemia, Sankt Petersburskije Vedomosti, Petersburskij Vestnik, Moskievskije Vedomosti, and by the St. Petersburg-Dutch Committee for the relief of Wounded Boers. The committee coordinated pro-Boer activities all over Russia.

The Polish society warmly supported the idea of diplomatic intervention of the European great powers on behalf of the Boers in order to restore peace in 
South Africa on such terms which would be acceptable for the Boers. When in March 1900 it eventually became evident that none of the great powers intended to intervene, Gazeta Warszawska wrote: "Everyone shows great compassion for the Dutch peasants, but neither will they help them nor stand up for them. No one has the courage to do so. When will the time for mediation come, which was so vehemently promised by European public opinion at the beginning of the war? Probably it never will. Well then, it's a small thing, but a great shame" (GW 2.03.1900). Similar comments were made after the failure of Paulus Kruger's trip to Europe in the fall of 1900. The policy of the German emperor William II was criticized as well. The Boers saw a glimmer of hope after receiving the so called "Kruger's telegram" in January 1896, in which the German monarch congratulated them on the averting of the Jameson raid and securing independence of their country. Yet then, in November 1900, William II refused even to meet Kruger who was asked to leave the German territory as soon as possible (GG 6.12.1900; Kr 9.03.1900; GW 24.09.1900).

The participation of Polish volunteers in the war for the independence of the Boer Republics was another measurable way of expressing support in this military conflict. 2600 European volunteers played an active part in the war. The number of Russian citizens was estimated at about 255. Poles were most certainly included in this figure, as their family names speak for themselves. At least a certain part of those bearing Polish-sounding names declared themselves as Poles. However, it is hard to determine the exact number of Poles as they were officially listed as Austrians, Germans or Russians. The number of Polish volunteers was certainly limited, taking into account the distance of $10,000 \mathrm{~km}$ to be covered, the high cost and a long journey going along with it. I would estimate that no more than 20 or 30 Poles fought on the side of the Boers.

Poles had various reasons and motivations for wanting to take part in this war. One of the prominent Polish liberals, influential publicist and writer Bolesław Prus sardonically noted in his press chronicle on 12 November 1899: "Young high school students, after reading about the brave Boers, hurried to help them" (Prus 1966: 300). Many articles on the issue, not without humoristic undertones, can be found in the press, especially during the last months of 1899 . Here are a few examples: “The son of one of Warsaw's residents, 15-year old Zygmunt Skrzeczkowski, left for school but didn't return home. He wanted to form a group with his friends to go and help the Boers. The meeting place was supposed to be a forest near Ząbkowice, close to the border" (Prus 1966: 633; S1 5.11.1899), "13-year old Edward Olechowski ran away from home in Szmulcowizna. He was found the next day in the meadows of Skaryszew, trembling with cold and hunger. He stated that he had decided to organize an expedition to the Transvaal but his friends hadn't turned up. With money that was intended for 
his school-fees he had bought tinned food and other things needed for his trip" (Prus 1966: 633), "14-year old Wawrzyniec Suchowolski, a son of a cook from Warsaw, was found in Pelcowizna yesterday. The young lad took his father's old shot-gun, a hunter's bag, and 6 rubles from his mother. This would-be ally of the Boers was caught by his father on the Petersburg highway and was taken home" (Prus 1966: 637; Sł 6.11.1899; KW 6.11.1899). There were also those who wanted to take part in the war only to radically improve their material situation. For them it made no difference on which side they were to fight, as long as they profited from it. According to the press some peasants planned to sell their small farms, which were insufficient to feed their large families, and go to war in the hope of obtaining larger allotments or money (Prus 1966: 317-318, 320, 367; KW 9.11.1899; Kr 24.11.1899).

In the first week of the war the Dutch consul in Warsaw received many letters with questions on how one could join the Boer army. Some candidates even visited him in the consulate building. The number of these questions was so high that the Dutch diplomat felt himself obliged to publish in the Polish press announcements in which he reminded potential candidates that the Netherlands had declared neutrality in the Anglo-Boer war, and due to that fact he could not help volunteers to get to the area of military operation (KW 06.11.1899, KW 14.11.1899; PT 18.11.1899). Kurier Warszawski was convincing its readers that despite the sympathy for the Boers this war was not worth a single drop of Polish blood (KW 19.11.1899). Also many potential volunteers lured by the gossip of 2,000 rubles per year for serving in South Africa asked the British council in Warsaw about the possibility of joining the British Army there (Sł 5.11.1899; GW 17.11.1900).

On the other hand, a strong pro-British stance was taken by the world-known Polish pianist Ignacy Paderewski. For example, the entire profit from his London concert given on 28 November 1899 was offered to a special relief fund for wounded and sick British soldiers and war orphans and widows. In an interview for the Chicago Times Herald, Paderewski claimed that European continental powers support the Boers against England which had given freedom to the world. Many Poles accused Paderewski - who, in their view, was ignorant, when judging the situation from the distance of the concert halls - of overlooking the invasive British policy and the fate of the Boer women and children (Żukowski 1994: 91-92; Wapiński 1999: 61). On the other hand, it was rather dislike and indignation, not hate, that dominated the picture of the British presented by the majority of the Polish press during the Second Boer War. Namely, still many Poles perceived Great Britain as a modern state, economy and society, with liberal political institutions, an example to follow in the reform of social institutions on Polish territories (Leśniewski 2001: 250; Jedlicki 2002; Janowski 1998; Kizwalter 1987: 656-679). 
A similar conclusion was drawn by the main ideologist of the Polish nationalism, Roman Dmowski. In his fundamental program book Myśli nowoczesnego Polaka [Thoughts of the modern Pole], Dmowski wrote: "England raped the Boer [...] Well, that's right, but 60 years ago the Boers raped the Kaffirs [...] who were turned by the newcomers [Boers - P.Sz.] into those deprived of all rights, made into drunken, working animals [...]. The Englishmen took the land from the Boers and will make better use of it" (Dmowski 1933: 197-199). Dmowski claimed that, regrettably, many Poles criticized the British violation of the Boer rights more vehemently than the German and Russian violations against the Polish. According to him, due to the fact that Germany publicly sympathized with the Boers, the Poles had no rational reason to support Afrikaners. Moreover, because he perceived the Boers as a potential ally of the German Reich, the greatest enemy of the Polish nation, their defeat meant a blow to the German position in the world politics (Dmowski 1938: 123-124). One of Dmowski's main protagonists, the leader of the socialist, pro-independence movement, future commander of the Polish Legions during the First World War and then an autocratic dictator, Józef Piłsudski, observed the Boer War as a theoretician of warfare. He drew a conclusion that the South African War proved the thesis that the losses on the contemporary battlefields were smaller than in former military conflicts (Piłsudski 1930: 76-77). After 1914 this conclusion turned out to be false.

Paradoxically, this standpoint was supported by the famous Polish novelist, Henryk Sienkiewicz, a future Nobel prize winner. At the beginning of 1900, the German peace activist Berta von Suttner appealed to the group of leading European intellectualists, among them Sienkiewicz, to sign a petition to British public opinion to take up steps to stop the war. Sienkiewicz refused to sign the petition arguing that, as a German, von Suttner should first protest against the persecution of Poles in Germany and subsequently intervene in the South African conflict. Instead of collecting money for the Boers he suggested financially helping starving people in the Wołga River's provinces in Russia. This open statement of his, an unquestioned moral authority, unleashed discussions in Polish public opinion (Nałkowski 1904: 12; Cz 1.03.1900; Kr 9.03.1900, Kr 6.04.1900, Kr 13.04.1900; NR 10.04.1900).

Sympathy or antipathy for the Boer cause coincided with political divisions, as on the example of Sienkiewicz's refusal to sign the appeal of European intellectuals to British elites. One commentator from the conservative weekly Kraj, Ludwik Starszewicz criticized him for not seeing humanitarian reasons and responding negatively to Suttner's request. Supporting the petition would enhance Sienkiewicz's moral right to condemn the Berlin government's Germanisation policy directed towards Poles (Kr 23.03.1900). But in the next issue, another journalist, Tomasz Smarzewski, supported the writer's stance arguing 
that his signature would not stop the British and would not prevent the outbreak of other wars in the future. Additionally, Boers were perceived as allies of Germany whose emperor William II had imperial ambitions and was hostile toward the Polish subjects (Kr 9.03.1900, Kr 23.03.1900, Kr 6.04.1900, Kr 13.04.1900).

From the very beginning of the war Polish observers did not believe in the idea of an international diplomatic intervention of the great powers for the Boers cause (KP 14.10.1899; Sł 2.03.1900; NR 19.12.1899; KL 20.12.1899; KW 11.11.1899). Perhaps this skepticism was a result of Polish past experience, when despite hopes and political calculations none of the great powers intervened successfully for the Polish cause during the national uprisings in the $19^{\text {th }}$ century (Szlanta 2016: 307-318). As Boleslaw Prus commented: "Christian and civilized Europe was entertained by the Transvaal War as if it were bulls or roosters fighting [...] Does not the behavior of Europe remind observers of street fights, who are watching a fight of a small boy against a giant, and are encouraging the first: Well done, little one! Don't give up! Hit him in his head! But when the giant grips his adversary hard by his neck, nobody thinks to rescue him, to help him" (Prus 1966: 491-496). This opinion was shared by the conservative journalist Tadeusz Żuk-Skarszewski who wrote:

What is happening could not have been avoided. The British army is marching through the Boers' land and the inevitable end is near. [...] A moment of a sad reckoning is coming for the Boers. [...] In the fight with a superior power, they could win the glory but will have to leave victory for the stronger party. [...] It is us, blasé Europeans, who encourage these simpletons to resist and to conduct the war, knowing well what the final result of this fight will be, we push them to doom, and then enjoy their bravery, an amusement for us while for them it is a matter of life and death. (Kr 9.03.1900)

In the second, guerilla, phase of the war, the Polish press condemned the non-humanitarian policy of concentration camps established by the British authorities for the Boer civil populace with the aim of cutting them from guerilla detachments still operating in the field. As in the January 1901 the widely read Kurier Warszawski commented:

When the news of barbarian acts of British mercenaries started to flow to Europe [...] it seemed at the beginning that they were intentionally widespread appeals of the Boer's agents aimed at awakening European compassion and instigating negative attitude towards the English invaders. Today, however, even London's newspapers confirm the terrible news and one can hardly doubt about the authenticity of the horrifying Vae victis, reporting the screams of raped women, and the crackle of burned-out 
abandoned farms, which delighted soldiers on the soil of the Transvaal and the Orange Free State, and speaking of the weeping of the defenseless and women and children being driven into captivity. (KW 10.01.1901)

Moreover, the press published many illustrations and cartoons depicting the brutality of the invaders (Mu 1.(14.)12.1900, Mu 11.(23.)02.1900, Mu 9.(22.)03.1901, Mu 1.(14.)02.1902, Mu 31.05(13.06)1902).

In order to make up for their organizational and tactical inefficiency the British army was believed to have applied inhumane and uncivilized methods of warfare, such as using dum-dum ammunitions, introducing the illegal blockade of Lourenço-Marques (contemporary Maputo), apprehending some neutral ships suspected of smuggling, and practicing the scorched earth policy during the guerilla period of the war. The British were accused of acting with the intention of physically annihilating the Afrikaners. The atrocities they committed were compared to the Belgian activities in the Congo. Even those with moderate opinions towards the war, those who simply sympathized with the British, distanced themselves from this controversial policy and dissociated from these methods. Bolesław Prus wrote: "From a moral point of view, Englishmen deserve a flogging for their outrages in the Transvaal [...] the present phase of the Transvaal campaign, with the burning of farms, raping of women, people suffering from severe diseases and imprisoning of children, begins to look like dealings of an executioner" (Prus 1967: 26-31). According to Prus, the acts of atrocity in the Transvaal reached such a scale, that it could not have possibly taken place without London's permission and knowledge (Prus 1967: 277).

The Polish press commented in editorials on the conclusion of peace in Vereeniging on May $31^{\text {st }} 1902$. One commentator stressed that the war did last surprisingly long and that the Boers stubbornly resisted against the world empire for over two years, forcing it finally to conclude the peace under compromising conditions (NR 4.06.1902; KW 21.05(3.06).1901; KL 4.06.1902; Cz 4.06.1902). As commented in Gazeta Grudziądzka, only few people were happy with the result of the war which had nothing to do with law and justice. "Poor Boers! They are not related to us either by language or by faith, but probably we, the Polish, could best understand the sad fate which befell them because also we had been deprived of our statehood and freedom" (GG 5.06.1902). Another newspaper from Prussian-Poland Kuryer Poznański, looked with hope into the future and offered words of consolation: "The Providence did not say the last word and maybe in a not too distant time it will allow the Boers to regain their freedom and independence, which they enjoyed before the English greed turned to their gold-bearing country. The blood of their heroes will give birth to avengers" (KP 4.06.1902). 


\section{Conclusion}

Astonishingly, the Boer War was followed by many Poles with a great interest, as reflected in the press and memoirs from that time. Despite some critical voices, the great part of the Polish society expressed pro-Boers ideas. Throughout the entire $19^{\text {th }}$ century the Polish many times took up arms and stirred up uprisings against the overwhelming enemy to regain independence. This similarity of fates of both nations did not go unnoticed by the Polish political, social and cultural elite. There was something romantic in the uncompromising Boer's stance against the powerful empire, something very close to the Polish political culture at that time, with its cult of fallen heroes. Generally, the Boers were idealized by the greatest part of the Polish public opinion and perceived in a simplified way, without going too deep into the complicated relations between them, the British and the African peoples. A few critical voices could not change this sentimental, subjective perspective in which the Boer soldiers embodied the universal topos of freedom fighters.

In my opinion, demonstrating sympathy toward the Boers, a small nation which dared to challenge a world empire in defense of its national right, was in Russian-Poland an indirect, veiled way of expressing disappointment with the policy of another empire, in this case Russia, towards another small nation - the Polish. As already mentioned Jan Gebethner put it in his memoirs: "At that time our political situation under Russian rule created such an atmosphere that every freedom movement, even in such a distant location as South Africa, aroused a vivid response among disparate social classes. The failures of the British were received with joy and Boers' victories were welcomed enthusiastically" (Gebethner 1977: 76). Seen from the perspective of the greatest part of Polish public opinion, the Boers personified the general idea of freedom fighters and symbolized all suppressed nations. Their unequal fight with the forces of British Empire was a symbol of a good cause. Also, some role was played by the exoticism of the topic (a war at the end of the world) for the inhabitants of East Central Europe and the huge disproportion of powers between the belligerents (as in the case of the biblical duel between David and Goliath) (Leśniewski 2001: 249-251; Kr 3.11.1899) I would risk the thesis that never before and never since have Poles followed a development of a political situation in South Africa with such eager interest and emotion as in the period 1899-1902.

\section{Bibliography}

Bender, Steffen. 2009. Der Burenkrieg und die deutschsprachige Presse. Wahrnehmung und Deutung zwischen Bureneuphorie und Anglophobie 1899-1902. Paderborn: Schöningh. 
Davidson, Apollon, and Irina Filatova. 1998. The Russians and the Anglo-Boer War. Cape Town: Human \& Rousseau.

De Wet, Christiaan Rudolf. 1903. Trzy lata wojny o niepodległość. Warszawa: n.p.

Dmowski, Roman. 1933. Myśli nowoczesnego Polaka. Warszawa: Komitet Wydawniczy Pism Romana Dmowskiego. 1938. Pisma. Vol. 3. Częstochowa: A. Gmachowski.

Gebethner, Jan. 1977. Młodość wydawcy. Warszawa: PIW.

Janowski, Maciej. 1998. Polska myśl liberalna do 1918 roku. Kraków-Warszawa: Znak.

Jedlicki, Jerzy. 2002. Jakiej cywilizacji Polacy potrzebują. Studia z dziejów idei i wyobraźni XIX wieku. Warszawa: WAB.

Kasprzycki, Jerzy. 1997. Korzenie miasta. Warszawa: Veda.

Kizwalter, Tomasz. 1987. "Ziemiaństwo połowy XIX w. wobec procesów modernizacji idee kręgu Andrzeja Zamoyskiego." Przegląd Historyczny 78(4): 656-679.

Kröll, Ulrich. 1973. Die Internationale Burenagitation 1899-1902. Münster: Verlag Regensberg.

Krüger, Paul. 1903. Pamiętniki prezydenta Krügera. Warszawa: A.T.Jezierski.

Kuoitenbrouwer, Vincent. 2012. War of Words. Dutch Pro-Boer Propaganda and the South African War (1899-1902). Amsterdam: Amsterdam University Press.

Leśniewski, Michał. 2001. Wojna burska 1899-1902. Geneza, przebieg i międzynarodowe uwarunkowania. Warszawa: Semper.

McCracken, Donald P. 2003. Forgotten Protest. Ireland and the Anglo-Boer War. Belfast: Ulster Historical Foundation.

Nałkowski, Wacław. 1904. Sienkiewicziana. Szkice do obrazu. Kraków: n.p.

Noer, Thomas J. 1978. Briton, Boer and Yankee. The United States and South Africa 1879-1914. Kent: Kent State Univ. Press.

Piłsudski, Józef. 1930. Pisma-mowy-rozkazy. Vol. 3. Warszawa: Inst. Badania Najnowszej Historji Polski.

Pottinger, Brian. 1986. The Foreign Volunteers. They Fought for the Boers (1899-1902). Pietermaritzburg: Scripta Africana.

Prus, Bolesław. 1966. Kroniki. Ed. Zygmunt Szweykowski. Vol. 16. Warszawa: PIW. 1967. Kroniki. Ed. Zygmunt Szweykowski. Vol. 27. Warszawa: PIW.

Rosenbach, Harald. 1981. Das Deutsche Reich, Großbitannien und der Transvaal 1896-1902. Göttingen: Vandenhoeck \& Rupprecht.

Szlanta, Piotr. 1997. "Transvaal in the German Policy in the Light of German and Polish Sources." Africana Bulletin 45: 45-64.

2016. “Der Januaraufstand in Russisch-Polen, die Autonomie in Österreichisch-Galizien und die Krise um Schleswig-Holstein. Die polnische Unabhängigkeitsbewegung im internationalen Kontext 1863-1864." Der Wiener Frieden 1864. Ein deutsches, europäisches und globales Ereignis. Eds Olivier Auge, Ulrich Lappenküper, and Ulf Morgenstern. Paderborn: Schöningh: 307-318

Teulié, Gilles. 2000. Les Afrikaners et la guerre anglo-boer 1899 - 1902: étude des cultures populaires et des mentalités en présence. Montpellier: Univ. Paul Valéry.

Wapiński, Roman. 1999. Ignacy Jan Paderewski. Wrocław: Zakład Narodowy im. Ossolińskich.

Zins, Henryk. 2000. Cecil Rhodes. Ekspansja brytyjska w Afryce pod koniec XIX wieku. Gdańsk: Polnord-Oskar.

Żukowski, Arkadiusz. 1994. Wkraju złota i diamentów. Polacy w Afryce Południowej XVI-XX wiek. Warszawa: PWN. 


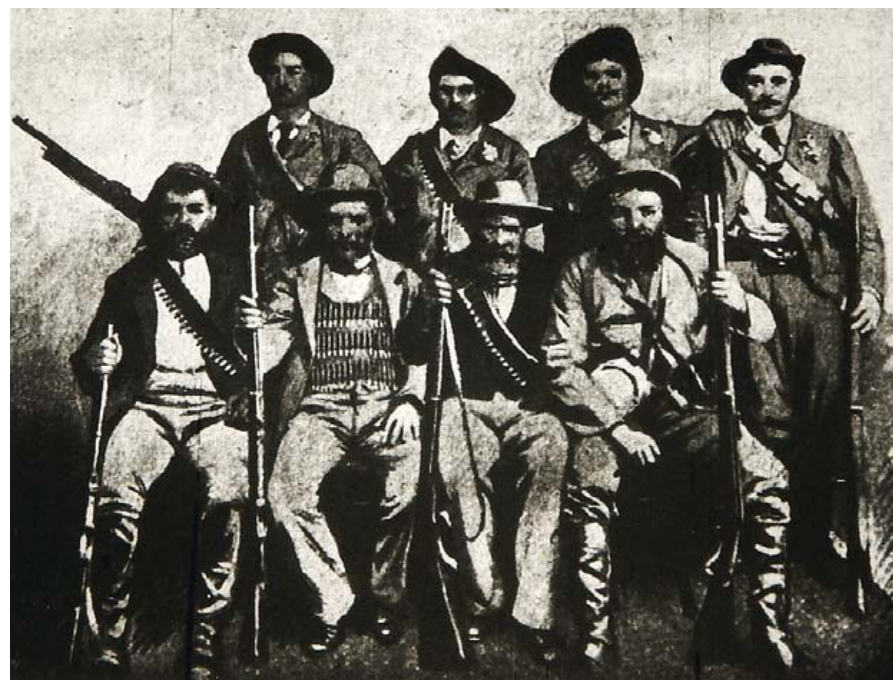

1. Group of Orange Free State's soldiers. Source: Tygodnik Ilustrowany: 30.10. (11.11.) 1899

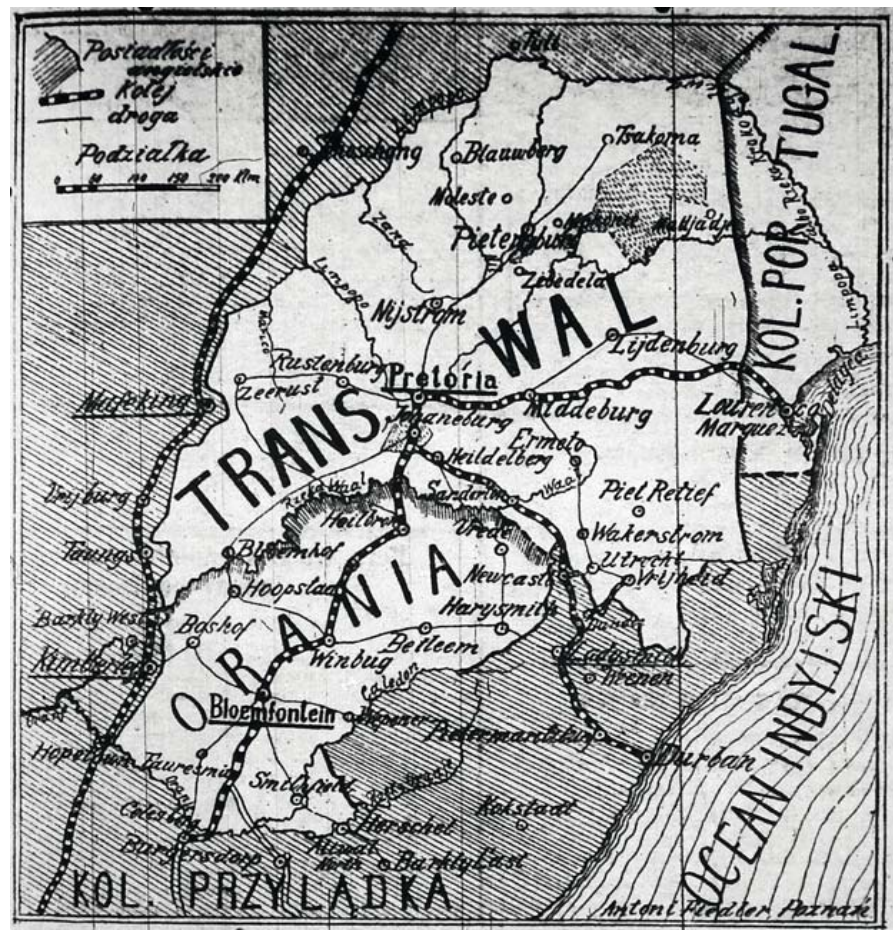

2. Map of South Africa. Source: Kuryer Poznański, 12.11.1899 


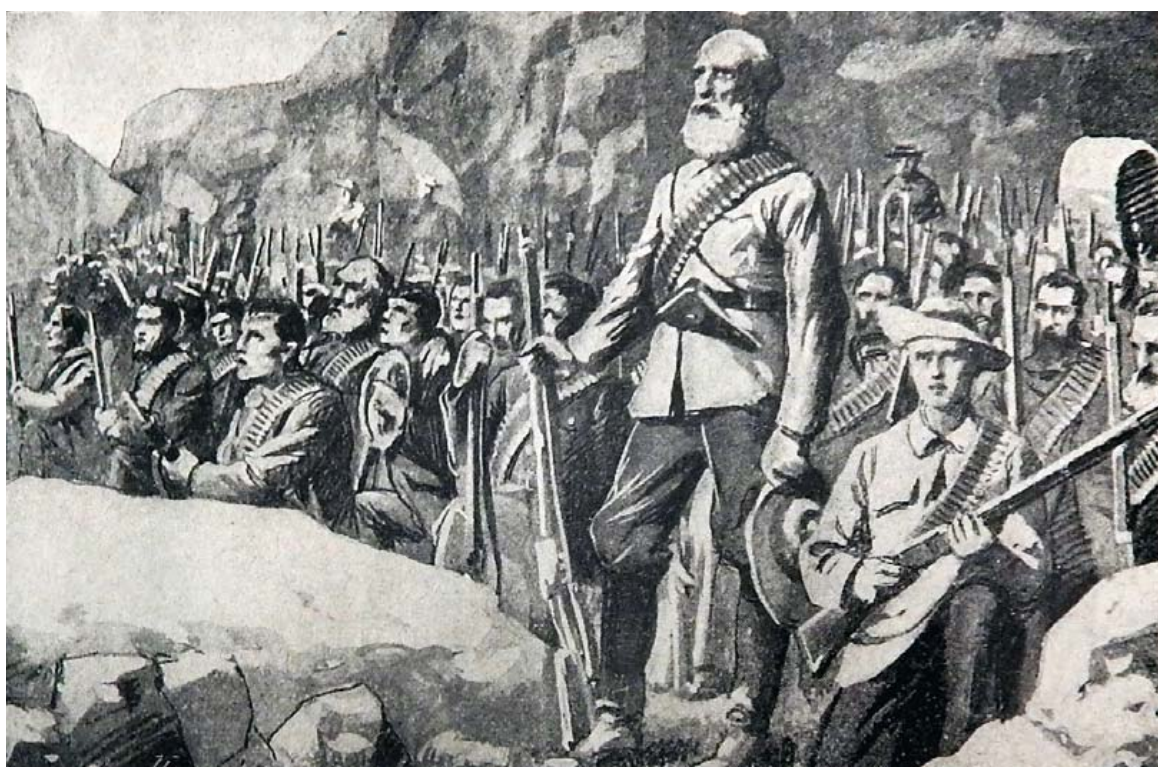

3. Boers are praying before a battle. Source: Tygodnik Ilustrowany, 3.02.(22.01.)1900

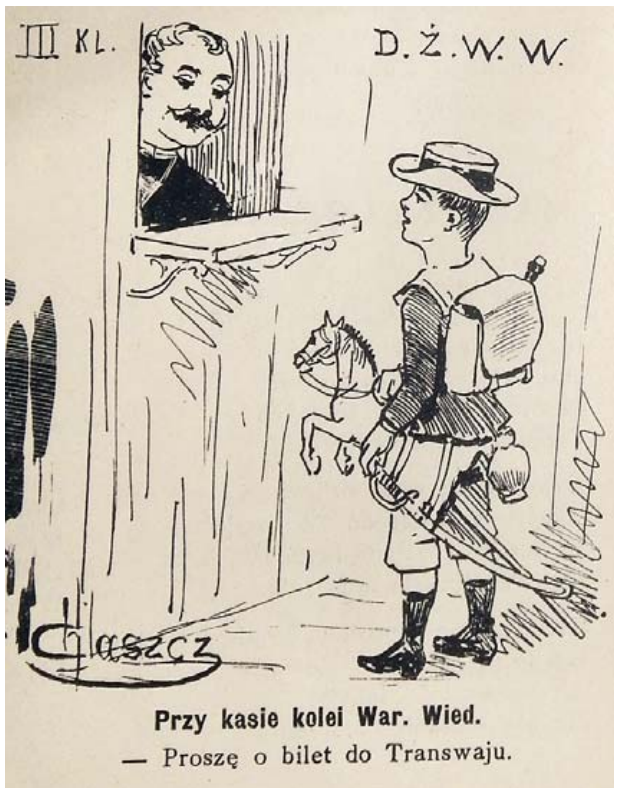

4. By the ticket office at the Warsaw railway station: Ticket to Transvaal please. Source: Kolce, 27.11(6.12). 1899

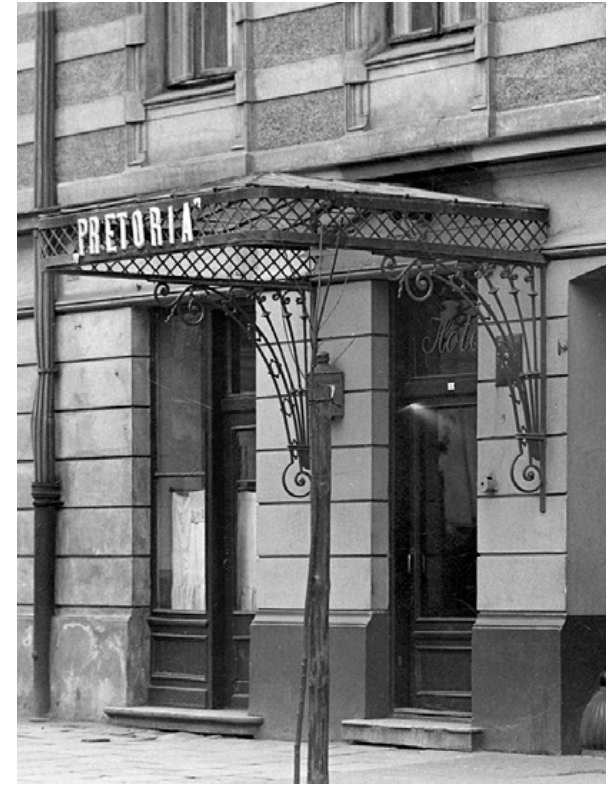

5. Hotel Pretoria in Warsaw, Zielna Street 17. Picture from interwar period. Source: Narodowe Archiwum Cyfrowe 
6. Ladysmith. Source: $M u$ cha, 26.11.(5.12.) 1899
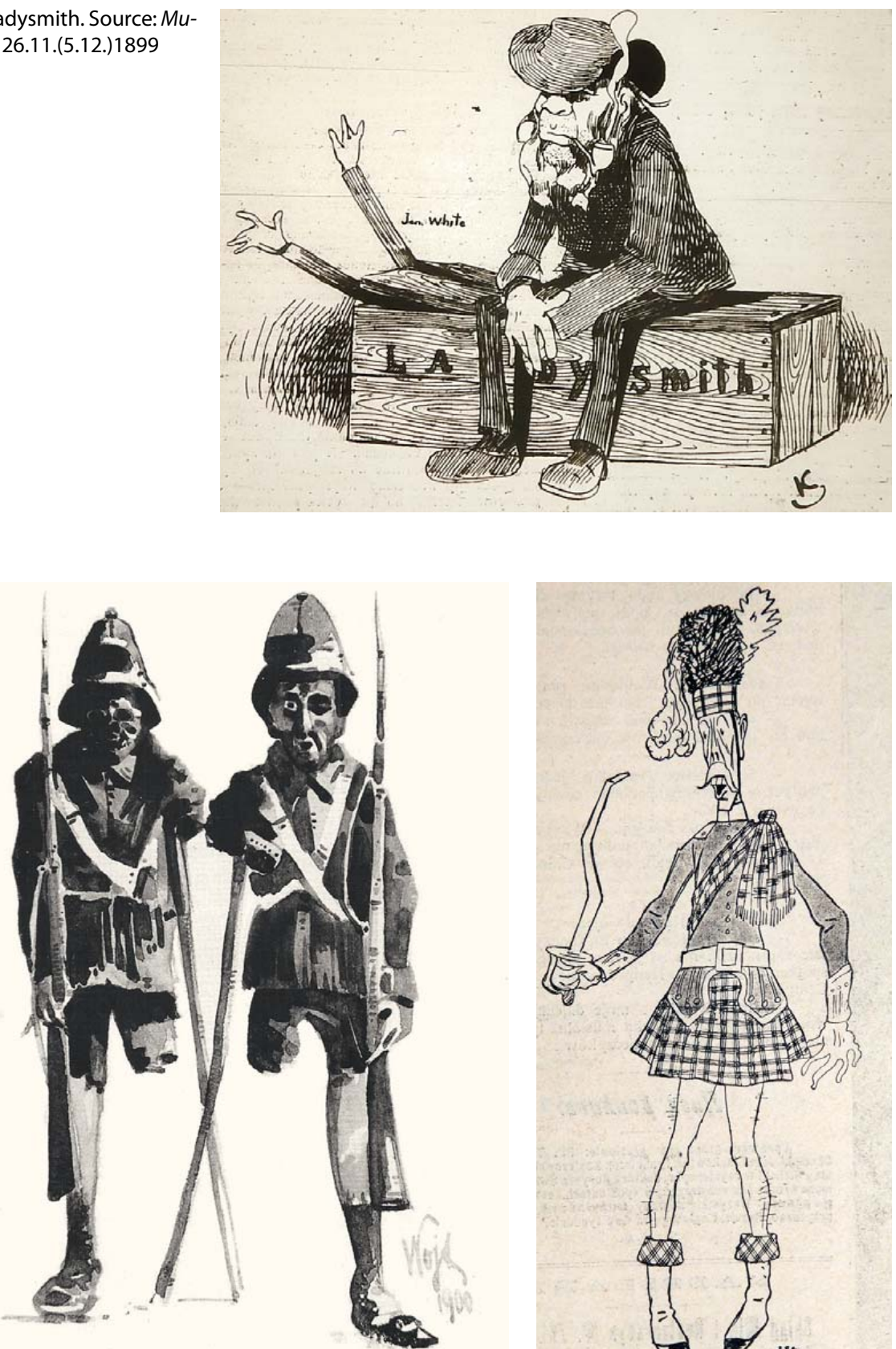

7. Brave English troops destined for the African expedition. Source: Kuryer Świateczny, 26.03(8.04)1900

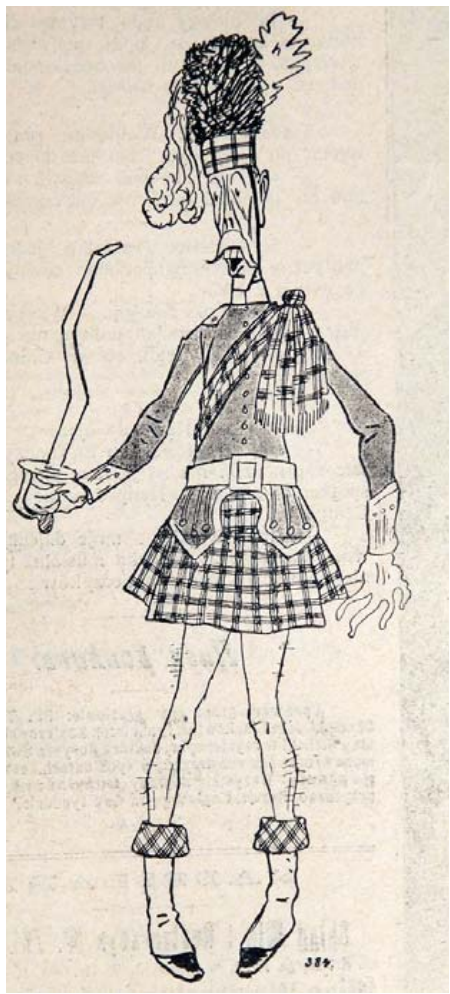

8. British arms. Source: Kuryer Świq̨teczny, 15.(18.) 10.1900 


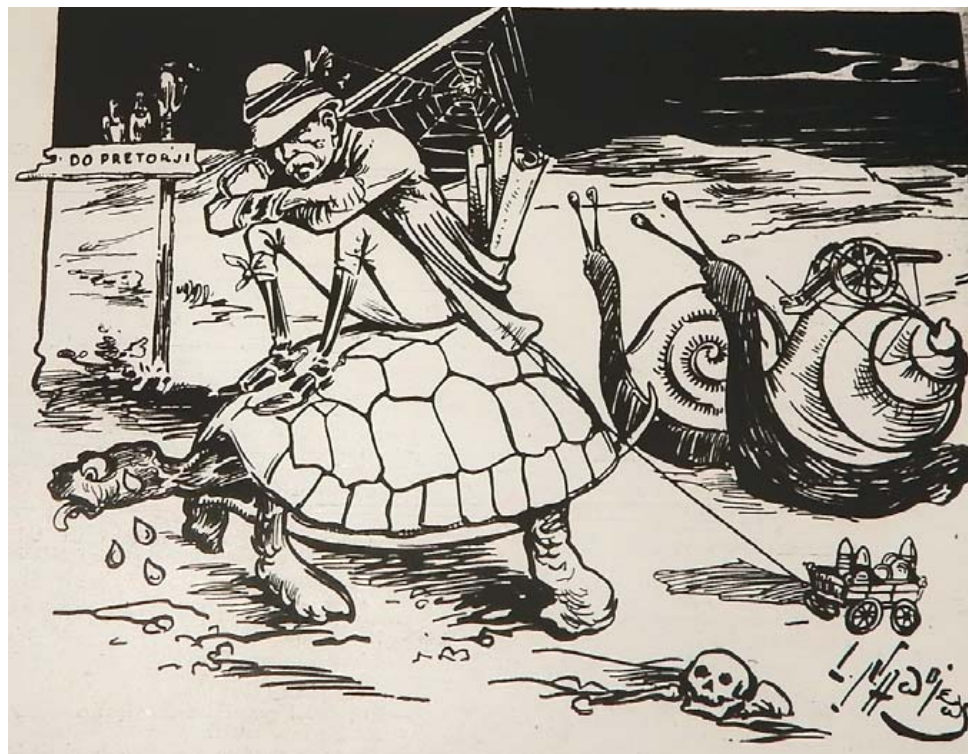

9. Roberts' March to Pretoria, Source: Mucha, 21.04.(5.05.)1900

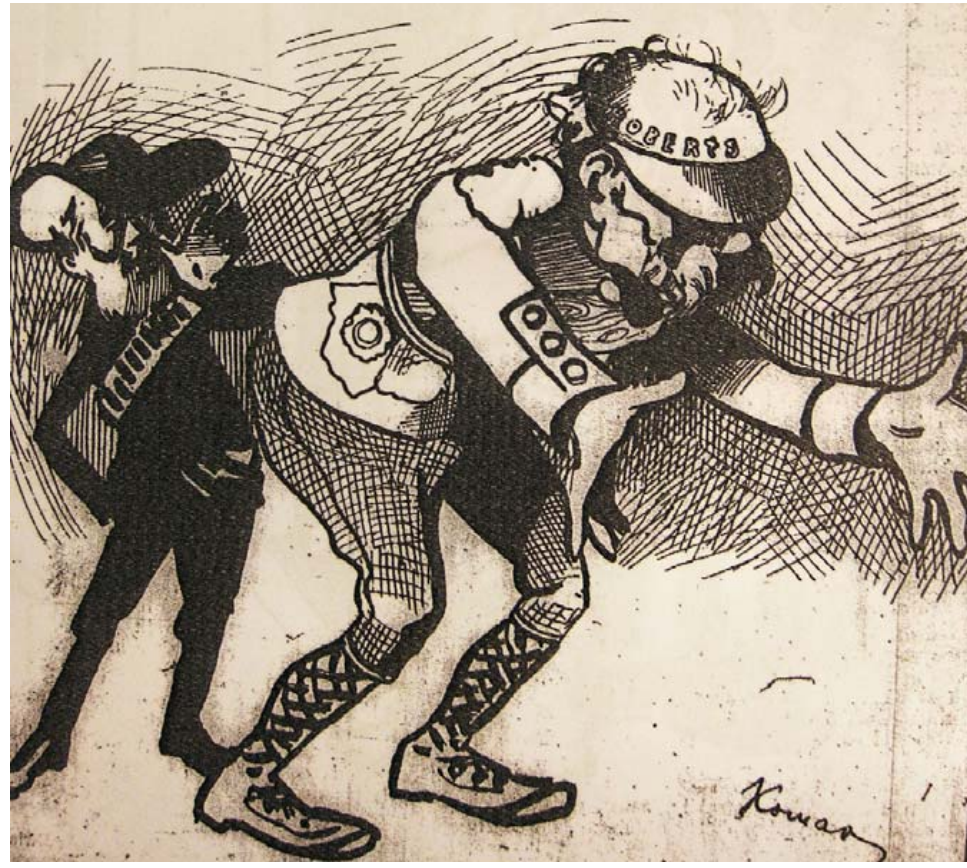

10. Playing blind man's buff with De Wet. Source: Mucha, 11.(24.)08.1900 
11. The British peace palm. Source: $K u$ ryer Świąteczny, 30.04.(13.05.)1900
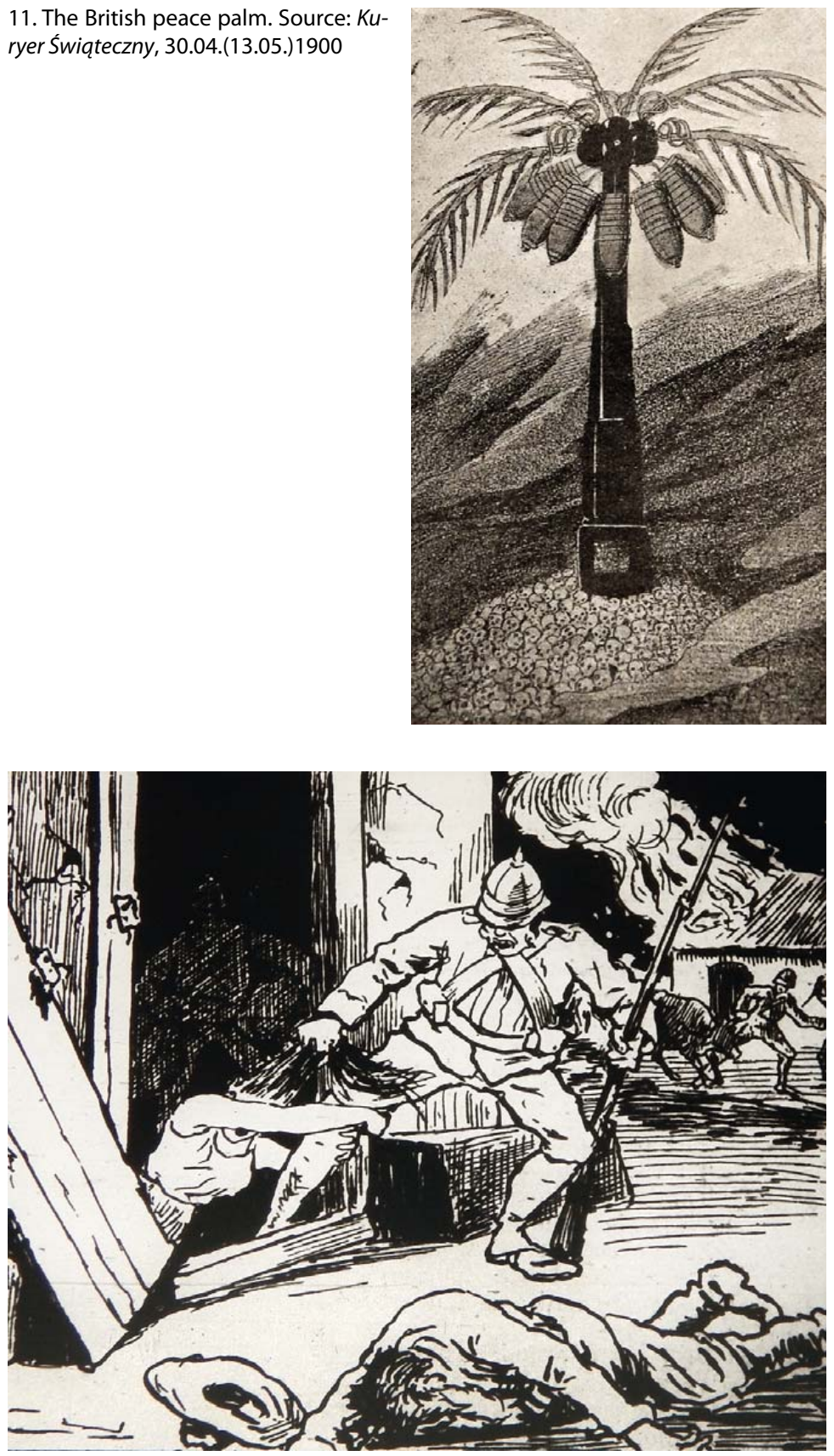

12. Apostles of the European Civilization. Englishmen in Transvaal. Source: Mucha, 1.(14.) 12.1900 


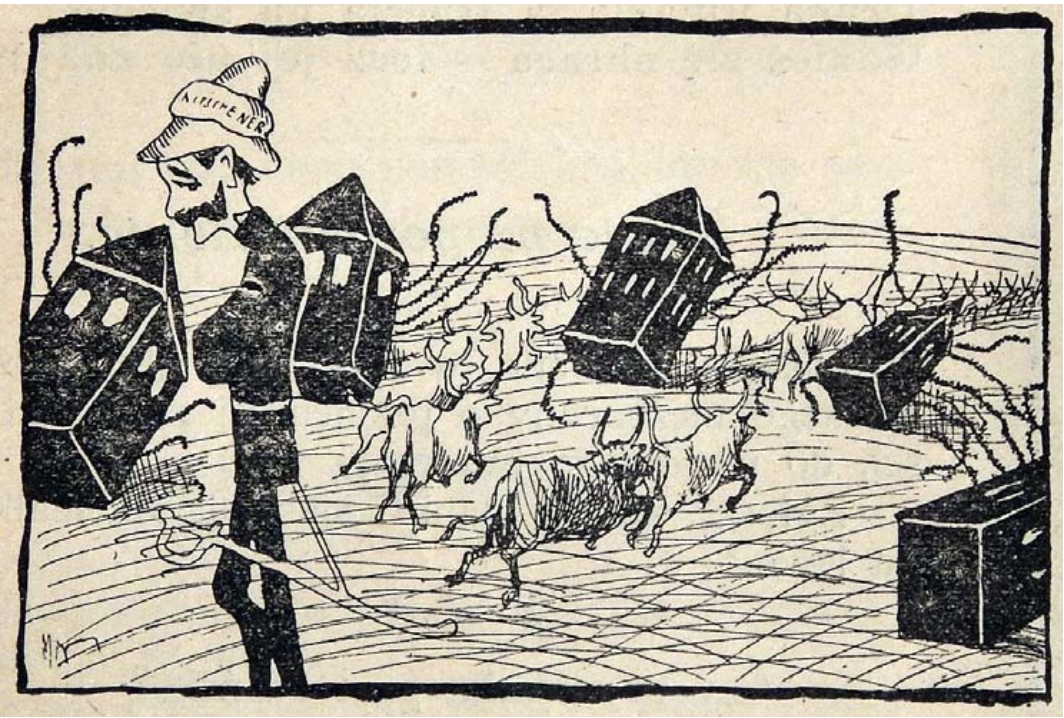

13. From the War. Blockhouse system of Kitchener was destroyed by bulls. Source: Kuryer Świąteczny, 26.04.(9.05.)1902

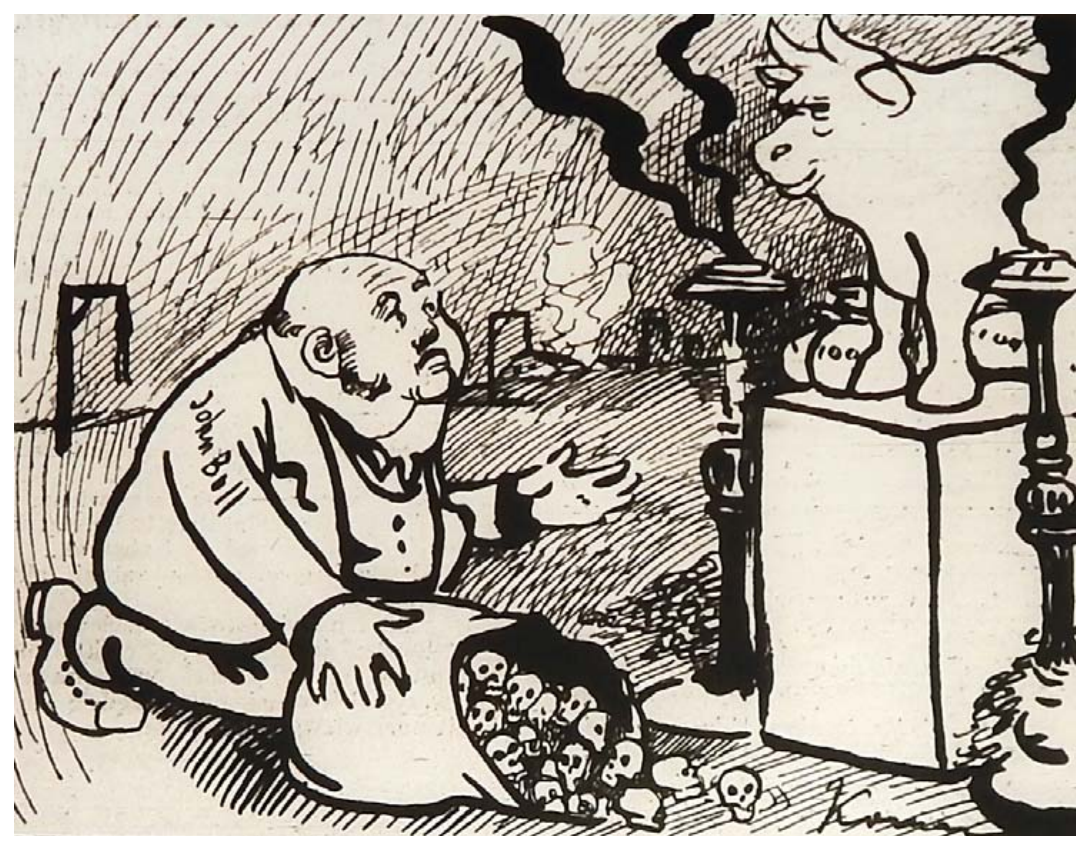

14. John Bull is making offerings before the golden calf after the war. Source: Mucha, 12.(25.)04. 1902 


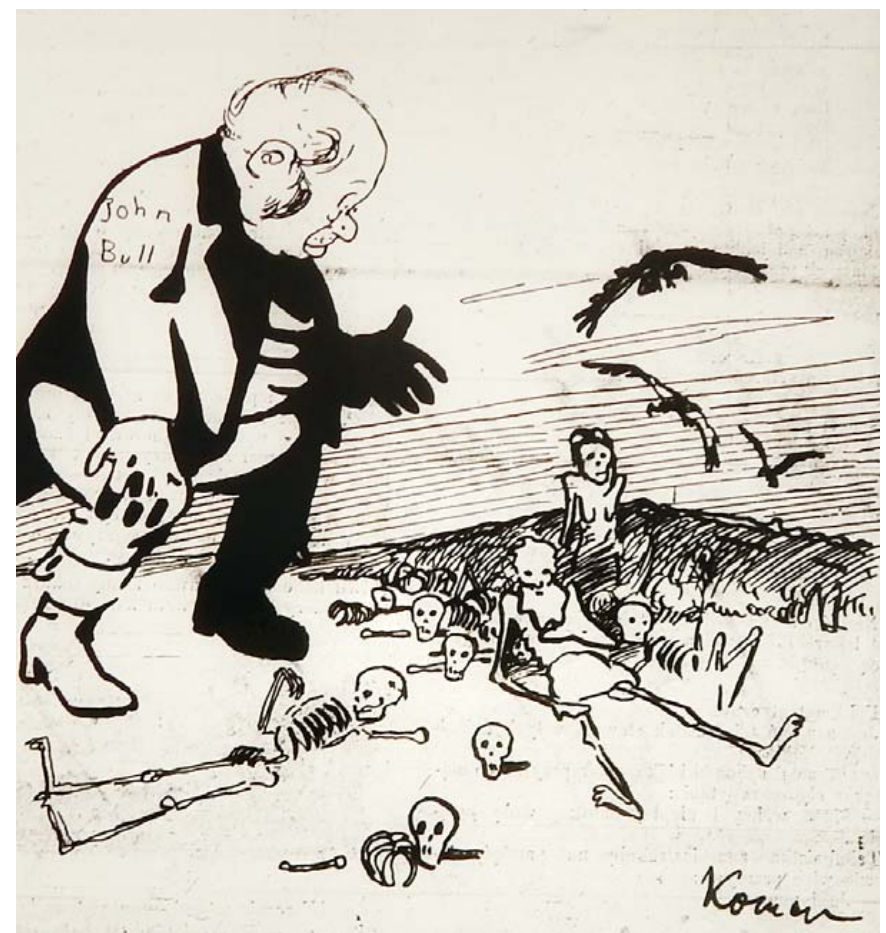

15. Cartoon on the British concentration camp policy in South Africa. Source: Mucha 1.(14.)02.1902 